\title{
A TEST OF Bombus terrestris COCOON AND OTHER COMMON METHODS FOR NEST INITIATION IN B. lapidarius AND B. hortorum
}

\author{
Alena Bučánková ${ }^{1,2}$, Vladimír Ptáček ${ }^{1}$ \\ ${ }^{1}$ Agricultural Research, Ltd. Troubsko, Czech Republic \\ ${ }^{2}$ Research Institute for Fodder Crops, Ltd. Troubsko, Czech Republic \\ e-mail: bucankova@vupt.cz
}

Received 11 April 2012; accepted 21 November 2012

S u m m a r y

Several methods for stimulating nest initiation (particularly the use of the Bombus terrestris cocoon) in queen bumblebees of the species B. lapidarius and B. hortorum were compared. For B. lapidarius, it was determined that the percentage success rate for establishing the first egg cell on a cocoon of $B$. terrestris is similar to that on a conspecific cocoon. Nest establishment, however, was significantly slower on the cocoon of $B$. terrestris. Moreover, it was determined that queens of B. lapidarius are able to initiate a nest without hibernation. Queens hibernated in the laboratory displayed a similar percentage success rate in establishing an egg cell during stimulation with the cocoon of $B$. terrestris as did the outdoor queens, but the lab queens established it significantly more slowly. Queens of B. hortorum did not incubate the cocoon of B. terrestris, nor did they establish an egg cell on it.

Keywords: bumblebee, cocoon, colony initiation, Bombus terrestris, Bombus lapidarius, Bombus hortorum.

\section{INTRODUCTION}

Bumblebees are important pollinators of many agricultural crops. During the past century, great advances have been made in research concerning bumblebee domestication. Today, several species are already being reared in commercial hives (Velthuis and Doorn, 2006).

The first important attempts at rearing bumblebees were made by Sladen(1912). He published his experience in the now legendary book, "The Humble-bee". The basis for certain stimulatory methods used today for stimulating queens' oviposition in the laboratory, can be traced to his experiments. These methods include, for example, the stimulatory effect of providing a brood, which today is most frequently used in the form of a male cocoon (Duchateau, 1994; Kwon et al., 2003); the method of two queens, later more developed by Plowright and Jay (1966), Alford (1975), Duchateau
(1985) and Ptáček (2000); the method of an added worker, later mentioned by Alford (1975); and the use of interspecies cooperation to initiate nesting of the queen and rearing of a brood (O no et al., 1994).

Bumblebees' willingness to accept a brood or an individual of another species is very advantageous. This permits the breeding of those bumblebee species not yet domesticated and for which a conspecific brood or worker is usually not available. For interspecies cooperation, callow workers or male cocoons of the species Bombus (Bombus) terrestris L. are most frequently used due to their easy breeding and availability. To date, the stimulatory effect of the $B$. terrestris cocoon has been detected in the species $B$. hypocrita hypocrita P., B. (Bombus) ignitus S., B. h. sapporoensis C. (Yoneda, 2008), Bombus (Bombus) lucorum L. (Bučánková and Ptáček, 2010) and Bombus (Bombus) cryptarum F. (Bučánková et al., 2011). Yet, not all bumblebee species seem 
to accept the cocoon of $B$. terrestris. In 1998, Přidal and Hofbauer published a study in which the cocoon of $B$. terrestris was not accepted by the queens of $B$. (Megabombus) pascuorum S. or B. (Pyrobombus) hypnorum. It was also stated by Yoneda (2008) that queens of other subgenera (B. (Pyrobombus) ardens S., B. (Diversobombus) diversu S. and B. (Thoracobombus) schrenkii M.) were much less stimulated by the cocoon of $B$. terrestris. Unfortunately, more details about the influence of phylogenetic relatedness on cooperation are not known.

In the first half of the 1980s, Ptáček reported another stimulatory method for the species B. terrestris which uses callow honeybee workers. In other species (B. (Pyrobombus) lapidarius, B. lucorum, B. hypnorum, B. (Pyrobombus) pratorum L., B. pascuorum, B. (Megabombus) hortorum and B. (Megabombus) ruderatus F.) this method did not work well (Ptáček, 1983, 1985).

For our study, we decided to test the possibilities of using the cocoon of $B$. terrestris and certain other stimulatory methods, in laboratory breeding of the species B. lapidarius L. and B. hortorum L. These species were selected because they have longer tongues than $B$. terrestris (Hanski, 1982). B. lapidarius L. and B. hortorum L. are therefore suitable for pollinating plants with a long flower tube which the $B$. terrestris cannot pollinate. Breeding proficiency would therefore, be a welcome advantage.

\section{MATERIALS AND METHODS}

Experiments were performed during the 2008-2011 time period. Queens were captured in the spring when they had not yet established nests at several sites in Moravia (the Czech Republic). On the same day as their capture or one day after, they were placed into plastic containers that were $14 \times 19 \times 7 \mathrm{~cm}$. The bottom of the container was covered with a piece of cardboard. They were provided with a $60 \%$ sugar solution $(90 \%$ sucrose and $10 \%$ fructose) and fresh pollen which was replaced daily. The containers were placed in a dark room at a temperature of $27^{\circ} \mathrm{C}$ with $60-80 \%$ humidity.

\section{Stimulation and breeding of \\ B. lapidarius queens}

\section{Queens from nature}

A total of 80 queens captured outdoors were tested. Twenty queens were offered a B. lapidarius (BL) cocoon, 43 queens were offered a $B$. terrestris (BT) cocoon, 10 queens were placed in a free pair, 2 queens were kept alone, and 5 queens had three callow honeybee workers added.

Cocoons were replaced as needed with fresh cocoons. The queens were inspected every day. The establishment and location (on the cocoon/not on the cocoon) of the first egg cell, emerging of the first worker, death and behaviour (incubation, aggression, antennae contact, lack of interest) and eventually the emergence of the first young queen were checked.

After the first workers emerged, the colony was transferred into a $26.5 \times 20 \times 20 \mathrm{~cm}$ wooden hive lined with a newspaper, then kept at a temperature of $23-25^{\circ} \mathrm{C}$ with $40-50 \%$ humidity. For easier manipulation, the top of the hive was covered with plastic film. An opening was cut in the centre of the plastic film. The top of the hive with plastic film was covered with a wooden lid. The queen colonies that had been captured outdoors, were fed mostly with fresh pollen.

Young queens emerged in the hive, attempted to leave it after several days. These queens were seen on the hive walls beneath the plastic film, trying to leave. They were collected and transferred into a glass box together with unrelated males. The glass box was covered with netting and placed out in the daylight. The individuals had both pollen and sugar solution available. After mating they were either removed from the glass box and placed together into a breeding container in the dark at room temperature with sugar solution or marked and placed back into the vivarium to mate again. The queens were then hibernated in a refrigerator at a temperature of $4-7^{\circ} \mathrm{C}$. 
Artificially hibernated queens

After 3-4 months, 16 hibernated queens were activated. Thirteen queens were given a $B$. terrestris cocoon, 2 queens had a $B$. lucorum cocoon, and 1 queen was kept alone.

Queens without hibernation

After being removed from the vivarium, 31 B. lapidarius queens were not hibernated, but were placed into a breeding space. of these, 6 queens were stimulated with a cocoon of $B$. lapidarius, 22 with a cocoon of $B$. terrestris, and 3 queens were kept alone.

Non-hibernated and hibernated queens were kept using the same methods as were the queens from outdoors, but, since they were generally bred out of season, they were provided mostly with dried or frozen pollen.

Stimulation and breeding of the

\section{B. hortorum queens}

The capture and breeding of $B$. hortorum were similar to those for the aforementioned B. lapidarius.

A total of 46 queens were tested. of these, 21 were offered a cocoon of $B$. terrestris, 6 queens were placed in separate pairs (queens were separated by a double mesh which allowed odour contact but prevented physical attack), 12 queens were kept alone, and 7 queens had three callow honeybee workers added.

The colonies of $B$. hortorum were reared during the season, so they were provided with fresh pollen in a tiny bowl. Since they were from the group of so-called pocket makers, who have difficulty in collecting pollen from a bowl, their broods also were sprinkled with fresh pollen every day.

Data was processed using the Statistica 10 program, and statistical tests were performed for those groups for which $\mathrm{n} \geq 6$. Pearson's chi-square test $\left(\chi^{2} \text { test }\right)^{\prime}$ was used to analyse the queens' success rates in reaching individual nest development stages. The influence of breeding methods on the number of days necessary for reaching the individual stages was analysed by ANOVA or t-test using logarithmically transformed data. In the case of non- homogeneity of variances, Welch's t-test was used. If the data did not conform to the conditions of parametric testing, even after being logarithmically transformed, they were evaluated using the Kruskal-Wallis one-way analysis of variance or the MannWhitney U test.

\section{RESULTS}

Comparison of stimulation methods and breeding success rate for B. lapidarius

Queens from the outdoors

In the case of the BL cocoon variant, $60 \%$ of the queens established an egg cell on the cocoon, and $85 \%$ of the queens established an egg cell - this includes egg cells on as well as not on the cocoon. In the group of queens with a BT cocoon, $60 \%$ of the queens also initiated on the cocoon, while $88 \%$ of the queens established an egg cell. No queen of the ten free pairs established an egg cell. of the two queens kept alone, neither initiated a nest. of the five queens kept with honeybees, three initiated a nest. The significant difference among these groups $(p<0.001)$ was due to the unsuccessfulness of the pair-method, as the difference in the success rate of establishing an egg cell between the queens stimulated by various cocoons is insignificant $\left(\chi^{2}=0.14 ; \mathrm{df}=1 ; \mathrm{p}=0.708\right)$.

Queens with BL cocoons had significantly shorter intervals in comparison to queens with BT cocoons. This means shorter intervals both in the number of days necessary for establishing an egg cell $(p=0.001)$ and in the number of days between egg cell establishment and emerging of the first worker $(p<0.001)$. Details are presented in Table 1.

Artificially hibernated queens

Of the hibernated queens which had a BT cocoon available, 54\% established an egg cell on the cocoon. In total, $77 \%$ of the queens with a BT cocoon established an egg cell. of the two queens having a BL cocoon available, one of them established an egg cell on the cocoon (Tab. 2). 
Number of B. lapidarius queens captured outdoors which established an egg cell, established an egg cell on a cocoon, and produced workers and queens (including the average number of these queens $\pm \mathrm{SD}$ )

\begin{tabular}{|c|c|c|c|c|c|c|}
\hline $\begin{array}{l}\text { Queens from } \\
\text { nature/the } \\
\text { outdoors }\end{array}$ & $\begin{array}{c}\text { Cocoon } \\
B L \\
(n=20)\end{array}$ & $\begin{array}{c}\text { Cocoon } \\
\text { BT } \\
(n=43)\end{array}$ & $\begin{array}{c}\text { Two } \\
\text { queens } \\
(n=10)\end{array}$ & $\begin{array}{l}\text { Single } \\
\text { queen } \\
(n=2)\end{array}$ & $\begin{array}{c}\text { Honey } \\
\text { bees } \\
(n=5)\end{array}$ & $\begin{array}{c}\text { Result of } \\
\text { the statistical } \\
\text { test }\end{array}$ \\
\hline Egg cell & $\begin{array}{l}17 / 20 \\
(85 \%)\end{array}$ & $\begin{array}{l}38 / 43 \\
(88 \%)\end{array}$ & 0/10 & $0 / 2$ & $\begin{array}{c}3 / 5 \\
(60 \%)\end{array}$ & $\begin{array}{c}\chi^{2}=35.489 \\
d f=2 \\
p<0.001\end{array}$ \\
\hline $\begin{array}{l}\text { Egg cell on } \\
\text { the cocoon }\end{array}$ & $\begin{array}{l}12 / 20 \\
(60 \%)\end{array}$ & $\begin{array}{l}26 / 43 \\
(60 \%)\end{array}$ & - & - & - & $\begin{array}{c}\chi^{2}=0.001 \\
d f=1 ; \\
p=0.972\end{array}$ \\
\hline Workers & $\begin{array}{c}17 / 17 \\
(100 \%)\end{array}$ & $\begin{array}{l}31 / 38 \\
(82 \%)\end{array}$ & - & - & $\begin{array}{c}3 / 3 \\
(100 \%)\end{array}$ & $\begin{array}{c}\chi^{2}=3.588 \\
d f=1 ; \\
p=0.058\end{array}$ \\
\hline $\begin{array}{l}\text { Young } \\
\text { queens }\end{array}$ & $\begin{array}{c}4 / 17 \\
(24 \%)\end{array}$ & $\begin{array}{c}11 / 31 \\
(35 \%)\end{array}$ & - & - & 0/3 & - \\
\hline $\begin{array}{l}\text { No. of young } \\
\text { queens }\end{array}$ & $17 \pm 18$ & $11 \pm 9$ & - & $\begin{array}{ll}- & -1 \\
-1\end{array}$ & - & - \\
\hline A-EC & $5 \pm 2$ & $12 \pm 9$ & $\begin{array}{l}- \\
-\end{array}$ & $\begin{array}{ll}- & -1 \\
-1\end{array}$ & $11 \pm 7$ & $\begin{array}{c}\text { Welch } \\
t=3.411 \\
d f=52.9 \\
p=0.001\end{array}$ \\
\hline EC-W & $22 \pm 8$ & $34 \pm 14$ & - & - & $39 \pm 30$ & $\begin{array}{l}U=102 ; \\
p<0.001\end{array}$ \\
\hline W-YQ & $67 \pm 8$ & $52 \pm 18$ & - & - & - & - \\
\hline
\end{tabular}

A-EC - the average number of days \pm SD the queens needed from activation to egg cell establishment $\mathrm{EC}-\mathrm{W}$ - the average number of days \pm SD from egg cell establishment to emergence of the first worker; W-YQ - days from emergence of the first worker to emergence of the first queen.

Data included into statistical evaluation $(n \geq 6)$ and the corresponding results of the given statistical test, if significant, are highlighted in bold.

Queens without hibernation

In the group of queens with a BL cocoon available, $100 \%$ established an egg cell, and $67 \%$ of the queens established it on the cocoon. In the group with a BT cocoon, $41 \%$ of the queens established an egg cell and $23 \%$ of the queens established it on the cocoon. Each of the three queens of the group left alone, established a nest. The difference between the queens with $\mathrm{BL}$ cocoons and BT cocoons is significant both in terms of total initiation success rate $(p=0.01)$ and in terms of success rate of initiation on the cocoon $(p=0.041)$. However, no significant difference was determined in the time interval between activation and establishment of the first egg cell ( $\mathrm{p}=0.185)$ (Tab. 3$)$.
Comparison of queens from the outdoors, without hibernation and with hibernation, stimulated by cocoon of $B$. terrestris

The queens differed significantly in the success rate for establishing the first egg cell $\left(\chi^{2}=9.997 ; \mathrm{df}=2 ; \mathrm{p}=0.007\right)$. Those queens without hibernation were significantly less successful than were queens from outdoors $\left(\chi^{2}=8.636 ; \mathrm{df}=1\right.$; $\mathrm{p}=0.003$ ), while the hibernated queens did not significantly differ from the other groups. Also, a significant difference in the speed of first egg cell establishment was observed $(\mathrm{F}=10.972 ; \mathrm{df}=2 ; \mathrm{p}<0.001)$. Subsequent comparison by Scheffé's method showed that queens from outdoors initiate significantly faster than do queens without hibernation $(p=0.007)$ and with hibernation $(\mathrm{p}=0.001)$. Differences in other variables were not significant (Tab. 1, 2, 3). 
Table 2 .

Number of B. lapidarius queens artificially hibernated which established an egg cell, established an egg cell on a cocoon, and produced workers and queens (including the average number of these queens $\pm \mathrm{SD}$ )

\begin{tabular}{||c|c|c|c||}
\hline $\begin{array}{c}\text { Afrtificially hibernated } \\
\text { queens }\end{array}$ & $\begin{array}{c}\text { Cocoon BT } \\
(\mathrm{n}=13)\end{array}$ & $\begin{array}{c}\text { Cocoon of } \\
\text { B. lucorum } \\
(\mathrm{n}=2)\end{array}$ & $\begin{array}{c}\text { Single } \\
\text { queen } \\
(\mathrm{n}=1)\end{array}$ \\
\hline Egg cell & $10 / 13(77 \%)$ & $1 / 2(50 \%)$ & $0 / 1$ \\
\hline Egg cell on the cocoon & $7 / 13(54 \%)$ & $1 / 2(50 \%)$ & - \\
\hline Workers & $7 / 10(70 \%)$ & $0 / 1$ & - \\
\hline Young queens & $2 / 7(29 \%)$ & - & - \\
\hline No. of young queens & $5 \pm 0$ & & \\
\hline A-EC & $29 \pm 12$ & 42 & - \\
\hline EC-W & $26 \pm 12$ & - & - \\
\hline W-YQ & $46 \pm 0$ & - & - \\
\hline
\end{tabular}

A-EC - the average number of days \pm SD the queens needed from activation to egg cell establishment; EC-W - the average number of days \pm SD from egg cell establishment to emergence of the first worker; $\mathrm{W}-\mathrm{YQ}$ - days from emergence of the first worker to emergence of the first queen.

Table 3 .

Number of B. lapidarius queens without hibernation which established an egg cell, established an egg cell on a cocoon, and produced workers and queens (including the average number of these queens $\pm \mathrm{SD}$ )

\begin{tabular}{|c|c|c|c|c|}
\hline $\begin{array}{l}\text { Queens without } \\
\text { hibernation }\end{array}$ & $\begin{array}{c}\text { Cocoon BL } \\
(n=6)\end{array}$ & $\begin{array}{c}\text { Cocoon BT } \\
(n=22)\end{array}$ & $\begin{array}{l}\text { Single queen } \\
(n=3)\end{array}$ & $\begin{array}{l}\text { Result of the } \\
\text { statistical test }\end{array}$ \\
\hline Egg cell & $6 / 6$ (100\%) & 9/22 (41 \%) & $3 / 3(100 \%)$ & $\begin{array}{c}\chi^{2}=6.618 \\
d f=1 ; \\
p=0.01\end{array}$ \\
\hline $\begin{array}{l}\text { Egg cell on } \\
\text { the cocoon }\end{array}$ & 4/6 (66 \%) & $5 / 22$ (23\%) & - & $\begin{array}{c}\chi^{2}=4.173 \\
d f=1 ; \\
p=0.041\end{array}$ \\
\hline Workers & $3 / 6$ (50\%) & 3/9 (33\%) & 1/3 (33\%) & $\begin{array}{c}\chi^{2}=0.417 ; \\
\text { df }=1 ; \\
p=0.519\end{array}$ \\
\hline Young queens & $2 / 3(66 \%)$ & $1 / 3(33 \%)$ & $1 / 1(100 \%)$ & - \\
\hline $\begin{array}{l}\text { No. of young } \\
\text { queens }\end{array}$ & $7 \pm 2$ & 23 & 60 & - \\
\hline$A-E C$ & $18 \pm 15(n=6)$ & $28 \pm 19(n=9)$ & $4 \pm 1(n=3)$ & $\begin{array}{c}\mathrm{t}=1.399 \\
\mathrm{df}=13 \\
\mathrm{p}=0.185\end{array}$ \\
\hline EC-W & $39 \pm 13(n=3)$ & $31 \pm 16(n=3)$ & $26(n=1)$ & - \\
\hline W-YQ & $42 \pm 5(n=2)$ & $45(n=1)$ & $38(n=1)$ & - \\
\hline
\end{tabular}

A-EC - the average number of days \pm SD the queens needed from activation to egg cell establishment; EC-W - the average number of days \pm SD from egg cell establishment to emergence of the first worker; W-YQ - days from emergence of the first worker to emergence of the first queen.

Data included into statistical evaluation $(n \geq 6)$ and the corresponding results of the given statistical test, if significant, are highlighted in bold. 
Number of B. lapidarius queens without regard to stimulation method used, which established an egg cell, established an egg cell on a cocoon, and produced workers and queens (including the average number of these queens $\pm \mathrm{SD}$ )

\begin{tabular}{|c|c|c|c|c|}
\hline - & $\begin{array}{c}\text { Queens } \\
\text { from nature/ } \\
\text { the outdoors } \\
(\mathrm{n}=82)\end{array}$ & $\begin{array}{c}\text { Artificially } \\
\text { hibernated } \\
\text { queens } \\
(n=16)\end{array}$ & $\begin{array}{c}\text { Queens } \\
\text { without } \\
\text { hibernation } \\
(n=31)\end{array}$ & $\begin{array}{l}\text { Result of the } \\
\text { statistical test }\end{array}$ \\
\hline Egg cell & $\begin{array}{c}62 / 82 \\
(76 \%)\end{array}$ & $\begin{array}{c}12 / 16 \\
(75 \%)\end{array}$ & $\begin{array}{c}18 / 31 \\
(58 \%)\end{array}$ & $\begin{array}{c}\chi^{2}=3.506 \\
d f=2 \\
p=0.173\end{array}$ \\
\hline Workers & $\begin{array}{l}54 / 62 \\
(87 \%)\end{array}$ & $\begin{array}{c}7112 \\
(58 \%)\end{array}$ & $\begin{array}{c}7118 \\
(39 \%)\end{array}$ & $\begin{array}{c}\chi^{2}=4.439 \\
d f=2 \\
p=0.109\end{array}$ \\
\hline $\begin{array}{l}\text { Young } \\
\text { queens }\end{array}$ & $\begin{array}{l}17154 \\
\text { (31\%) }\end{array}$ & $\begin{array}{c}2 / 7 \\
(29 \%)\end{array}$ & $\begin{array}{c}4 / 7 \\
(57 \%)\end{array}$ & $\begin{array}{c}\chi^{2}=1.919 \\
d f=2 ; \\
p=0.383\end{array}$ \\
\hline $\begin{array}{l}\text { No. of young } \\
\text { queens }\end{array}$ & $15 \pm 12$ & $5 \pm 0$ & $24 \pm 25$ & - \\
\hline$A-E C$ & $10 \pm 8$ & $27 \pm 11$ & $20 \pm 18$ & $\begin{array}{c}H=21.645 \\
d f=2 \\
p<0.001\end{array}$ \\
\hline EC-W & $31 \pm 15$ & $26 \pm 12$ & $34 \pm 13$ & $\begin{array}{c}\mathrm{H}=1.283 \\
\mathrm{df}=2 \\
\mathrm{p}=0.527\end{array}$ \\
\hline W-YQ & $56 \pm 17$ & $97 \pm 0$ & $42 \pm 4$ & - \\
\hline
\end{tabular}

A-EC - the average number of days \pm SD the queens needed from activation to egg cell establishment; EC-W - the average number of days \pm SD from egg cell establishment to emergence of the first worker; W-YQ - days from emergence of the first worker to emergence of the first queen.

Data included into statistical evaluation $(n \geq 6)$ and the corresponding results of the given statistical test, if significant, are highlighted in bold

Comparison of queens from the outdoors, without hibernation and with hibernation, regardless of the stimulation method

When comparing queens without regard to the stimulation method used, those from outdoors, those without hibernation, and those hibernated were about equally successful in establishing egg cells $(p=0.173)$, but they differed in the speed of establishing the first egg cell $(p<0.001)$. Subsequent multivariate comparison showed that queens from outdoors require a significantly lower number of days to establish an egg cell than do hibernated queens $(p<0.001)$ and than do queens without hibernation $(\mathrm{p}=0.05)$. No significant difference was determined between the hibernated and non-hibernated queens $(U=82.5 ; p=0.167)$. No statistically significant differences were discovered among the remaining variables (Tab. 4).
Comparison of stimulation methods and breeding success rate for $B$. hortorum

In the group of queens with BT cocoons, $57 \%$ of queens established an egg cell on the cardboard, but no queen established it on the cocoon, and its incubation was not recorded. In the group of separated pairs, $66 \%$ of the queens established an egg cell. In the group of queens with honeybees added, $71 \%$ of the queens established an egg cell. of the queens kept alone, 100\% of the queens established an egg cell.

No significant difference in the number of days necessary for establishing the first egg cell or of the emerging of the first worker was observed between the individual stimulation variants. Queens with a BT cocoon unexpectedly had a better success rate in emerging of young queens in comparison to queens without special stimulation $(\mathrm{p}=0.025)$ (Tab. 5).

The overall success rate of the $B$. hortorum queens regardless of the stimulation method, is described in Table 6. 
Table 5 .

Number of B. hortorum queens captured outdoors which established an egg cell, established an egg cell on a cocoon, and produced workers and queens (including the average number of these queens $\pm \mathrm{SD}$ )

\begin{tabular}{|c|c|c|c|c|c|}
\hline & $\begin{array}{l}\text { Cocoon BT } \\
(n=21)\end{array}$ & \begin{tabular}{|c|} 
Separated \\
pair of queens \\
$(n=6)$
\end{tabular} & $\begin{array}{l}\text { Single queen } \\
\qquad(n=9)\end{array}$ & $\begin{array}{l}\text { Honey bees } \\
\quad(n=7)\end{array}$ & $\begin{array}{l}\text { Result of the } \\
\text { statistical test }\end{array}$ \\
\hline Egg cell & $12 / 21$ & $4 / 6$ & 9/9 & $6 / 7$ & $\begin{array}{c}\chi^{2}=6.55 \\
d f=3 \\
p=0.088\end{array}$ \\
\hline $\begin{array}{l}\text { Egg cell on } \\
\text { the cocoon }\end{array}$ & 0/21 & - & - & - & - \\
\hline Workers & 9/12 & $3 / 4$ & 6/11 & $4 / 6$ & $\begin{array}{c}\chi^{2}=1.067 ; \\
d f=2 ; \\
p=0.586\end{array}$ \\
\hline $\begin{array}{l}\text { Young } \\
\text { queens }\end{array}$ & $5 / 9$ & $1 / 3$ & $0 / 6$ & $2 / 4$ & $\begin{array}{c}\chi^{2}=5 ; \\
\mathrm{df}=1 ; p=0.025\end{array}$ \\
\hline $\begin{array}{c}\text { No. of young } \\
\text { queens }\end{array}$ & $10 \pm 8$ & 7 & - & $9 \pm 10$ & - \\
\hline$A-E C$ & $14 \pm 13$ & $10 \pm 6$ & $12 \pm 9$ & $9 \pm 5$ & $\begin{array}{c}F=0.171 \\
d f=2 \\
p=0.844\end{array}$ \\
\hline EC-W & $32 \pm 8$ & $43 \pm 19$ & $30 \pm 5$ & $40 \pm 30$ & $\begin{array}{c}t=0.59 \\
d f=11 ; \\
p=0.567\end{array}$ \\
\hline W-YQ & $38 \pm 21$ & 36 & - & 10 & - \\
\hline
\end{tabular}

A-EC - the average number of days \pm SD the queens needed from activation to egg cell establishment; EC-W - the average number of days \pm SD from egg cell establishment to emergence of the first worker; W-YQ - days from emergence of the first worker to emergence of the first queen.

Data included into statistical evaluation $(n \geq 6)$ and the corresponding results of the given statistical test, if significant, are highlighted in bold.

Table 6.

Number of B. hortorum queens which established an egg cell, and produced workers and queens (including the average number of these queens $\pm \mathrm{SD}$ )

\begin{tabular}{||c|c||}
\hline & $(\mathrm{n}=51)$ \\
\hline Egg cell & $37(73 \%)$ \\
\hline Workers & $23(62 \%)$ \\
\hline Young queens & $10(27 \%)$ \\
\hline No. of young queens & $10 \pm 7$ \\
\hline A-EC & $13 \pm 10$ \\
\hline EC-W & $32 \pm 13$ \\
\hline W-YQ & $33 \pm 20$ \\
\hline
\end{tabular}

A-EC - the average number of days \pm SD the queens needed from activation to egg cell establishment; $\mathrm{EC}-\mathrm{W}$ - the average number of days \pm SD from egg cell establishment to emergence of the first worker; W-YQ - days from emergence of the first worker to emergence of the first queen 


\section{DISCUSSION}

Although the queens without hibernation are significantly less successful when stimulated by a male BT cocoon than are queens from outdoors, it is evident that the $B$. lapidarius queens accept the BT cocoon as a place for establishing the first egg cell. In the case of queens from the outdoors, they even accept a BT cocoon as often as they do cocoons of their own species. It is interesting, that the lower success rate of queens without hibernation occurred only with the BT cocoon method. When comparing queens regardless of the stimulation method, this difference vanishes.

The significant differences in the speeds of egg cell establishment are a new finding. While on the conspecific cocoon, the outdoor queens establish an egg cell after an average of five days. It takes the outdoor queens more than double that, on a BT cocoon (Tab. 1). Also, the time necessary for the queen to raise the first worker is significantly increased. The number of days between the first egg cell and emerging of the first queens remains the same. For this reason, it is highly probable that this delay is negatively reflected in the number of workers, instead of which young queens are raised. Unfortunately, we usually had the hibernated queens and queens without hibernation available out of season. We did not have BL cocoons available out of season. This meant that we could not demonstrably prove whether queens would achieve better results on conspecific cocoons. The analysis of the non-hibernated queens with a BL cocoon $(n=5)$ and of the queens with a BT cocoon $(n=9)$ which established an egg cell, did not prove there to be a difference in the number of days between activation and the first egg cell.

Even though outdoor queens initiate more slowly on BT cocoons (12 days), they nevertheless are significantly faster than hibernating queens or queens without hibernation ( 27 and 28 days, respectively) on the same cocoon. a generally faster initiation by the outdoor queens is understandable. The outdoor queens had already been active for some time before their capture. Although we have no proof of this, we find it very probable that the number of days between awakening from hibernation and the establishment of an egg cell is approximately the same.

An unwanted increase in the number of days necessary for initiating a nest, which apparently also affects the number of workers, is caused by BT cocoons. The use of BT cocoons in continuous breeding, though, is easier and more advantageous than using $\mathrm{BL}$ cocoons. Cocoons of $\mathrm{BL}$ occur in close proximity to other cocoons of the same batch and it is practically impossible to separate them without damage. The only possibility for individualizing the cocoons comes at the price of either destroying neighbouring ones or using the entire batch, which can have a devastating effect on the donor nest.

We also tested the use of callow honeybee workers. P táček (1985) had not observed any cooperation between $B$. lapidarius and honeybees. For this reason, we used only five queens in the experiment which was to confirm the ineffectiveness of this stimulatory method. To our surprise, three queens displayed signs of accepting the bees (non-aggressiveness, antennae contact) and the bees occurred on the brood of the queen similarly to $B$. terrestris. In order to confirm the cooperation with the honeybee, the experiment needs to be repeated in higher numbers.

We also consider it interesting, that one of the two queens established an egg cell on the cocoon of B. lucorum. Again in this case, unfortunately, the experiment was not performed in a sufficient number of repetitions. Nevertheless, information on using cocoons of species other than $B$. terrestris is not very common, so we decided to include this case. Placing the queens in free pairs did not prove very effective for outdoor queens.

Another observation is the ability for the queens of $B$. lapidarius to initiate a nest without hibernation and without anaesthetization by $\mathrm{CO}_{2}$. The possibility 
of activating queens without hibernation is advantageous from the viewpoint of laboratory breeding. Death of queens is frequent during hibernation, and the economic costs of hibernation also are not negligible. We have discovered that a large proportion of already fertilized queens do not display pre-hibernation behaviour common in $B$. terrestris (filled abdomen, settling at one spot). Therefore, we did not hibernate these queens but instead transferred them into the breeding space. The already fertilized queens were then stimulated by $\mathrm{BT}$ or $\mathrm{BL}$ cocoons in the breeding space. The cause for the absence of pre-hibernation behaviour is not known, but we have repeatedly observed that if queens are kept with the males after fertilization, they mate several times. The highest number of matings we recorded was 3. Fliszkiewicz (2002) determined that queens of $B$. terrestris captured outdoors in spring, had larger numbers of sperm in the spermathecae than did queens mating in the laboratory. As in nature, the queens of this species usually mate only once (Schmidt-Hempel and Schmidt-Hempel, 2000), it is therefore possible that repeated mating was a response to insufficient mating.

While there is no problem with the species B. lapidarius accepting BT cocoons, the opposite is true for $B$. hortorum. of the 21 queens which were offered the male BT cocoon, in only one case was occasional incubation of the cocoon recorded. None of the queens established an egg cell on the cocoon. In one case, the queen repeatedly bit through the BT cocoon and threw out the pupa. Aggressive behaviour also occurred toward honeybees. In most instances, honeybees repeatedly died by the second day. In two cases, one bee was still alive during the establishment of an egg cell. The bee was not communicating with the queen though, and showed no interest in the brood. It appeared there was an apparent lack of success of these stimulatory methods, yet the success rate of the egg cell establishment was relatively high in all variants (57-92\%, Tab. 5). However, this success rate must be attributed mainly to the fact that queens captured in nature/from the outdoors are apparently so physiologically prepared for laying that they do not need much stimulation. We also observed frequent spontaneous laying in other queens of the Megabombus subgenus. The problem was with the hibernated queens. According to our experience dealing with the breeding and hibernation of several species, we found that only a small number of hibernated queens are able to produce a brood without external stimuli. At the turn of 2011/2012, we activated queens of $B$. hortorum acquired from the stated hives. Due to the small number of queens (10), we tested various combinations of stimulatory methods: separated pair, subsequently open pair, adding a male cocoon or a worker of $B$. terrestris. Initiation was not observed, however, even after one month. When we continued the stimulation, we recorded behavioural changes in three queens. At first, some of them sometimes incubated the maternal BT cocoon. After two months, two queens accepted the brood and the workers of $B$. terrestris, and actively participated in caring for the brood. Unfortunately, they did not raise their own offspring and only the workers of $B$. terrestris were laying. These queens had only frozen and dried pollen at their disposal. It is possible that unsuccessful breeding was not caused by the stimulatory methods but by inappropriate pollen.

As these problems do not occur in $B$. lapidarius, this species is more suitable for laboratory breeding in order to pollinate plants with a longer floral tube. Once the best method for preparing the queens for hibernation is resolved, the breeding of $B$. lapidarius will then be considered accomplished.

\section{CONCLUSION}

$B$. terrestris cocoons are accepted by the queens of $B$. lapidarius as a place for establishing the first egg cell as often as are cocoons of their own species. They establish egg cells on $B$. terrestris cocoons significantly more slowly, and it takes them 
significantly longer to raise the first worker. This slowdown may have a negative impact on the total number of workers. The speed of initiation on cocoons of $B$. terrestris is also affected by other conditions. The queens overwintering in the laboratory or activated without hibernation need significantly longer to establish an egg cell on the cocoons of $B$. terrestris than do the queens from outdoors. Nevertheless, the stimulus of the cocoon of $B$. terrestris on the queens' oviposition can be considered a great aid to breeding techniques. It seems that callow worker honeybees can also be used for the stimulation of queens. Another finding was the ability of the queens of B. lapidarius to lay eggs without hibernation and without anaesthetization by $\mathrm{CO}_{2}$. When the problems of mating, and the best method of preparing queens for hibernation are resolved, then breeding of $B$. lapidarius can be considered as having been accomplished. In contrast to $B$. lapidaries, the B. terrestris cocoons were never accepted by $B$. hortorum queens. The callow bees were repeatedly killed and displayed no signs of cooperation. Nevertheless, queens captured outdoors were initiating in large numbers. This spontaneous initiation apparently does not occur in the following generations in a laboratory and continuous breeding is still problematic.

\section{ACKNOWLEDGEMENTS}

We express our thanks to Jan Votava for his assistance in the preparation in this article. This study was financed by research project No. TA01020969 funded by the Technology Agency of the Czech Republic.

\section{REFERENCES}

Alford D. V. (1975) - Bumblebees, DavisPoynter, London.

Bučánková A., Ptáček V. (2010) Experiences in rearing of Bombus lucorum L. (Hymenoptera: Apoidea) in captivity. Úroda, 12, Vědecká př́loha, 621-624.
Bučánková A., Komzáková O., Cholastová T., Ptáček V. (2011) Notes on distribution of Bombus cryptarum (Hymenoptera, Apoidea) in Moravian territory (Czech Republic) and its laboratory rearing. Acta univ. agric. et silvic. Mendel. Brun., 6: 69-73.

Duchateau M. J. (1985) - Analysis of some methods for rearing bumblebee colonies. Apidologie, 16: 225-227.

Duchateau M. J., Toshiba H., Velthuis H. H. W. (1994) - Diploid males in the bumblebee Bombus terrestris. Entomol. Exp. Appl., 71: 623-269.

Fliszkiewicz M. (2002) - Causes of the lack of diapause in bumble bee females (Bombus Latr., Apoidea). J. Apic. Sci., 46: 31-40.

Hanski I. (1982) - Structure in bumblebee communities. Ann. Zool. Fennici., 19: 319-326.

Kwon Y. J., Saeed S., Duchateau M. J., (2003) - Stimulation of colony initiation and colony development in Bombus terrestris by adding a male pupa: the influence of age and orientation. Apidologie, 34: 429-437.

Ono M., Mitsuhata M., Sasaki M.,(1994) - Use of Introduced Bombus terestris Worker Helpers for Rapid Development of Japanese Native B. hypocrita Colonies (Hymenoptera, Apidae). Appl. Entomol. Zool., 29: 413-419.

Plowright R. C., Jay S. C. (1966) - Rearing bumblebee colonies in captivity. J. Apic. Res., 5: 155-165.

Ptáček V. (1983) - Indukce plodování samiček čmeláků (Hymenoptera, Bombidae) pomocí kontaktu se včelami medonosnými (Apis mellifera L.). (Stimulation of egg laying in bumblebee queens by means of their contact with honey bees). (Pilot study), SB. věd. prac. VŠÚP Troubsko 8, 157-161. (Cz. En. Sum.)

Ptáček V. (1985) - Zkoušky tř́ metod chovu čmeláků (Hymenoptera, Bombidae). (Testing three methods of rearing bumblebees.) SB. věd. prací, OSEVA, VŠÚP Troubsko, 9 , 56-57. (Cz. En. Sum.) 
Ptáček V., Pernová E., Borovec R. Sladen F. W. L. (1912) - The humble-bee, (2000) - The two-queen cascade method as an alternative technique for starting bumble bee (Bombus, Hymenoptera, Apidae) colonies in laboratory (Preliminary study). Pszczeln. Zesz. Nauk., 44: 305-309.

Přidal A., Hofbauer J. (1998) - Activation of laboratory-reared bumblebee queens (Hymenoptera: Apidae, Bombus spp.). Acta univ. agric. et silvic. Mendel. Brun., 46: 79-84.

Schmidt-Hempel R., Schmidt-Hempel P. (2000) - Female mating frequency in Bombus ssp. From Central Europe, Insect. Soc., 47: MacMillan, London.

Velthuis H. H. W., Doorn A. V. (2006) - a century of advances in bumblebee domestication and the economic and environmental aspects of its commercialization for pollination. Apidologie, 37: 421-451.

Yoneda M. (2008) - Induction of colony initiation by Japanese native bumble bees using cocoons of the exotic bumblebee Bombus terrestris. Entomological Science, 11: $123-126$. 36-41.

\title{
PRÓBA WYKORZYSTANIA KOKONÓW Bombus terrestris ORAZ INNYCH METOD INICJACJI ZAKLADANIA GNIAZD PRZEZ MATKI B. lapidarius I B. hortorum
}

\author{
Bučánková A., Ptáček V.
}

\author{
S t r e s z c z e n i e
}

Porównano kilka metod stymulacji zakładania gniazd (ze szczególnym uwzględnieniem wykorzystania kokonów Bombus terrestris) przez matki B. lapidarius i B. hortorum. Stwierdzono, że procent matek $B$. lapidarius, które wybudowały pierwszą miseczkę na jaja na kokonie $B$. terrestris był zbliżony do procenta matek, które wybudowały pierwszą miseczkę na kokonach własnego gatunku. Jednak budowanie gniazda na kokonach $B$. terrestris przebiegało znacznie wolniej. Stwierdzono również, że matki $B$. lapidarius, które nie hibernowały były zdolne do zakładania gniazda. Zbadano także jaki procent matek zbudował pierwszą miseczkę na kokonie B. terrestris w zależności od warunków hibernacji. Matki hibernujące w warunkach laboratoryjnych osiagnęły podobne wyniki do matek hibernujących w warunkach naturalnych. Zbudowanie pierwszej miseczki zajęło im jednak znacznie więcej czasu. Matki B. hortorum nie inkubowały kokonów B. terrestris. Nie budowały na nich również miseczek na jaja.

Słowa kluczowe: trzmiel, kokon, inicjacja rodziny, Bombus terrestris, Bombus lapidarius, Bombus hortorum. 